\title{
Soft Skills and Job Satisfaction: Two Models in Comparison
}

\author{
Claudio Palumbo \\ University of Parma -Italy \\ *Corresponding Author: claudio.palumbo@unipr.it
}

Copyright (C) 2013 Horizon Research Publishing All rights reserved.

\begin{abstract}
The implementation of soft skills has direct effects on the job satisfaction and motivation to work. The comparison between the two general models presented here proposes an area of research that, in addition to confirming the validity of the above correlations, intends to draw the attention to the need to make soft skills object of researches through more operational categories.
\end{abstract}

Keywords Soft Skills, Job Satisfaction, Motivation to Work

\section{Introduction}

Skill is a structured set of knowledge, abilities and attitudes necessary for the effective performance of a working task.

The soft nature of a skill concerns the possibility of being used by a same subject in more different contexts. This is not a characteristic of certain topics (such as communication), but rather a method of action of intentional subject that makes possible the use of their functionality in different contexts (eg: at work, with friends, family, in the couple relationship, etc.).

Moreover, soft is so that you can make use of certain skills, which, more than others, lend themselves to being transferred from one context to another.

If you receive this addition to a structured set of elements, the user should be able to transfer to different contexts of his personal and professional experience, then will have materialized the soft of the skills which needs of intentional actions to direct its implementation. Therefore, the correct question to ask is not "what are soft skills" but "what make soft the skills". The answer consists in the possibility that the skills (with different potentials) have to be acquired in a certain activity, solve problems and achieve desired outcomes (Palumbo, 2006; 2013)

\section{Methodology}

The Model presented here (Palumbo, 2011) is based on the continuum and the intersection of the factors high skills / low skills (Figure 1), or innate skills which are easily developing / skills be acquired with greater difficulties.

As can be seen from the model, in the condition of 'Flexible Profile', in addition to grow the high skills, he also as well as to grow the skills high, it also improves the skills low; at the other extreme we have the 'Unstable Profile', this profile is not interested in progressing in both skills; the 'Rigid Profile' focuses only on the development of high skills; at the other extreme, the 'Underused Profile', deals with low skills, job task from which it draws little satisfaction, but being aware of their high skills, is motivated to develop them in the future (Palumbo, 2006; 2010).

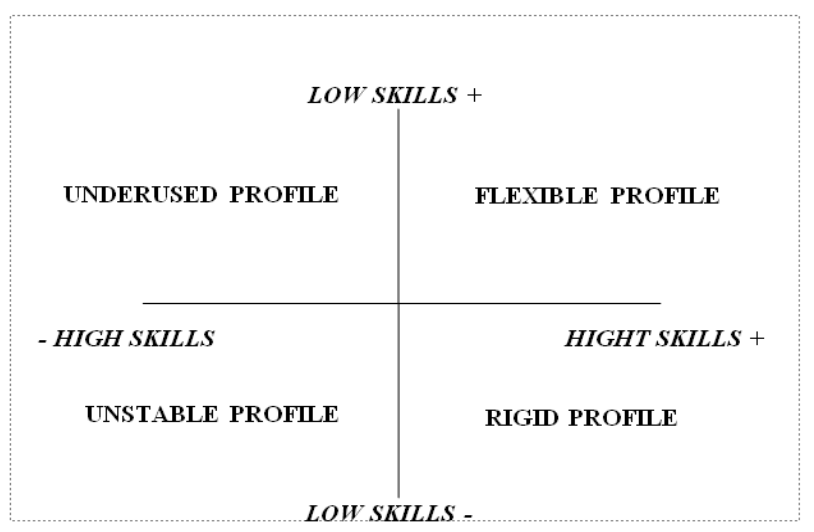

Figure 1. Soft Skills Model

The Soft Skills Model also has a clear compatibility to that of Figure 2, which relates to the Model Motivation / Satisfaction (Quaglino, 1999).

- A low motivation corresponds to a low satisfaction, reporting in this case the presence of a link oriented substantially to 'Waiver';

- a low motivation corresponds to high satisfaction, recognizing the presence of a positive link but limited to 'Implementation';

- a low satisfaction corresponds to high motivation, recognizing the presence of a link able to understand the 
dimension of external 'Challenge';

- a high motivation corresponds to high satisfaction, finding marks of an orientation modulated by the 'Involvement' as an expression of internal challenge.

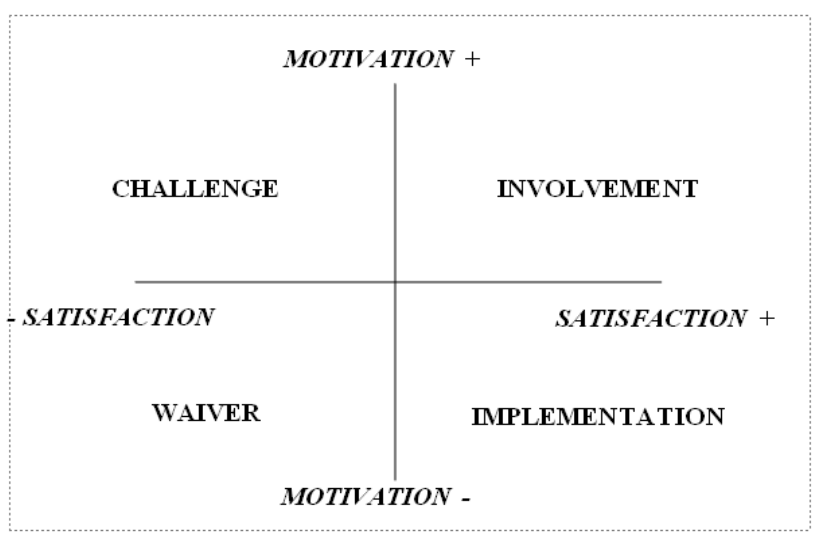

Figure 2. Motivation / Satisfaction Model

The condition of Unstable Profile is reflected in the Waiver to pursue the increase of high skills, much less the low skills so that at a low motivation corresponds a low satisfaction.

The Rigid Profile relates the Implementation, because the satisfaction is high based on the continuous use of high skills, but the motivation is low because it is not strengthened by the growth of low skills.

The condition of Underused Profile is identified in the Challenge, because, despite being in the situation of those who are involved in activities they do not like, especially because they do not use the high skills, they have the knowledge of the latter and the hope of using them in the near future.

The condition of Flexible Profile is the mirror image to the Involvement, where the motivation and satisfaction are both high.

In order to verify the correlation between the two models were prepared two questionnaires.

The first questionnaire is relative to the Soft Skills Model. The questions concern the context work and outside and refer to convictions and behaviors related to soft skills high and low. The categories of reference questions are as follows (Palumbo, 2013):

1. the ability to communicate to others;

2. the capacity to work in a group;

3. the ability to solve problems;

4. the ability to efficiently manage with difficult situations especially in terms of relational;

5.the ability to think, to raise awareness compared to influences and guiding owns their own thought, reaching in this way to a better control of the same;

6. the capacity to make an assessment of their skill and their level of growth, in order to make possible the soft potentially contained therein.

The questionnaire consists of 48 questions with responses true or false and distributed in 4 scales (of 12 questions each). The scales are related respectively to the 4 profiles:

- Flexible Profile

- Unstable Profile

- Rigid Profile

- Underused Profile.

The instrument demonstrates satisfactory statistical parameters. Reliability coefficient was $\alpha=0.93$, while for individual scales it ranged from 0.82 to 0.92 .

The second questionnaire is relative to the Motivation / Satisfaction Model. The questions concern the "Theory two-factor" of Herzberg (1959) that distinguishes between two types of factors:

- maintenance or hygiene factors: extrinsic characteristics of work that allow the satisfaction of basic needs and prevent dissatisfaction;

- motivating factors: intrinsic elements of work that allow the satisfaction of needs higher (closer to self).

In summary, I place the factors in the hierarchical order of importance according to the continuum "motivation satisfaction (maintenance)" (Palumbo, 2006; 2010):

- Nature intrinsic of work

- Achievement of results

- Possibility of professional growth

- Liability assumed

- Received recognition

- Professional promotion

- Prestige of the company

- Relationship with:

- The higher

- Peers

- Subordinates

- Technical competence of superiors

- Policies and procedures of the company

- Warranty workplace

- Manufacturing processes

- Physical conditions of work

- Level of remuneration

The questionnaire consists of the following 16 questions on the expectation of job satisfaction (the question is: 'What is more important for you in a job?'), with response scale from 1 (less important) to 10 (most important) (Palumbo, 2006; 2010):

- Relations with colleagues subordinate

- The level of responsibilities

- Organization strategies

- The prestige of the organization

- The phisical conditions of work

- The contents of work

- The skill of superiors

- Relations with co-workers at the same position

- Achieving of results

- Warranty workplace

- The opportunity to professional growth

- The relationship with higher

- Recognize the merits

- The level of salary

- Career opportunities 


\section{- Methods of works}

The research was carried out on a group of 144 employees aged between 25/60: 67 ( 32 men and 35 women) belonging to private companies, 77 (36 men and 41 women) employees belonging to public companies.

\section{Results}

The following correlations are related to the 4 profiles in the Soft Skills Model and 16 questions on expectation of job satisfaction. In order to make the table clearer, only statistically significant correlations at a level not lower than $\mathrm{p}<0.05$ were included (Table 1 ).

\section{Discussion}

The results presented in Table 1, as assumed by two Models, indicate that the Flexible Profile is correlated with the factors of motivation hierarchically higher; in the case of private companies, with Achieving of results and Opportunity to professional growth, in the case of public companies, with Contents of work, Achieving of results and more with Career opportunities. Flexible Profile is also correlated with the factors of satisfaction (maintenance factors): Relations with co-workers at the same position and
Methods of works (private and public companies).

Underused Profile, confirming the relation between the two Models, is correlated with Opportunity to professional growth, Level of responsibilities and Recognize the merits, in the case of private companies, with Level of responsibilities, Recognize the merits and Career opportunities, in the case of public companies: it is in fact all correlations with motivating factors.

Rigid Profile correlates only with the factors of satisfaction: Skill of superiors (public companies), Organization strategies (private and public companies), Warranty workplace (private companies), Phisical conditions of work (private companies). These correlations confirm the relation between the two Models, as well as a further confirmation comes from the negative correlation with the factor Recognize the merits (motivating factor).

Finally, also the absence of significant correlations (ie at a level not lower than $\mathrm{p}<0.05$ ) between Unstable Profile and both the motivating factors that satisfaction factors further confirms the validity of the relation between the two Models.

The Models described in this article of course require further research to arrive at convincing explanations and point to the need to make the soft skills the subject of research through more operational categories.

Table 1. Significant correlations

\begin{tabular}{|c|c|c|c|c|c|c|c|c|}
\hline & \multicolumn{4}{|c|}{ Private companies } & \multicolumn{4}{|c|}{ Public companies } \\
\hline & $\begin{array}{c}\text { Flexible } \\
\text { Profile }\end{array}$ & $\begin{array}{l}\text { Unstable } \\
\text { Profile }\end{array}$ & $\begin{array}{l}\text { Rigid } \\
\text { Profile }\end{array}$ & $\begin{array}{l}\text { Underused } \\
\text { Profile }\end{array}$ & $\begin{array}{l}\text { Flexible } \\
\text { Profile }\end{array}$ & $\begin{array}{l}\text { Unstable } \\
\text { Profile }\end{array}$ & Rigid Profile & $\begin{array}{l}\text { Underused } \\
\text { Profile }\end{array}$ \\
\hline Contents work & & & & & $\begin{array}{c}0.275 \\
p=0.02\end{array}$ & & & \\
\hline Achieving results & $\begin{array}{c}0.414 \\
p=0.01\end{array}$ & & & & $\begin{array}{c}0.392 \\
p=0.01\end{array}$ & & & \\
\hline $\begin{array}{l}\text { Opportunity } \\
\text { professional } \\
\text { growth }\end{array}$ & $\begin{array}{c}0.398 \\
p=0.01\end{array}$ & & & $\begin{array}{c}0.357 \\
\mathrm{p}=0.01\end{array}$ & & & & \\
\hline $\begin{array}{c}\text { Level } \\
\text { responsibilities }\end{array}$ & & & & $\begin{array}{c}0.315 \\
p=0.01\end{array}$ & & & & $\begin{array}{c}0.289 \\
p=0.02\end{array}$ \\
\hline Recognize merits & & & $\begin{array}{l}-0.238 \\
p=0.05\end{array}$ & $\begin{array}{c}0.285 \\
p=0.02\end{array}$ & & & & $\begin{array}{c}0.361 \\
p=0.01\end{array}$ \\
\hline $\begin{array}{c}\text { Career } \\
\text { opportunities }\end{array}$ & & & & & $\begin{array}{c}0.251 \\
p=0.05\end{array}$ & & & $\begin{array}{c}0.254 \\
\mathrm{p}=0.05\end{array}$ \\
\hline $\begin{array}{c}\text { Relations } \\
\text { co-workers same } \\
\text { position }\end{array}$ & $\begin{array}{c}0.353 \\
p=0.01\end{array}$ & & & & $\begin{array}{c}0.383 \\
\mathrm{p}=0.01\end{array}$ & & & \\
\hline Skill superiors & & & & & & & $\begin{array}{c}0.342 \\
\mathrm{p}=0.01\end{array}$ & \\
\hline $\begin{array}{c}\text { Organization } \\
\text { strategies }\end{array}$ & & & $\begin{array}{c}0.349 \\
\mathrm{p}=0.01\end{array}$ & & & & $\begin{array}{c}0.271 \\
\mathrm{p}=0.02\end{array}$ & \\
\hline $\begin{array}{c}\text { Warranty } \\
\text { workplace }\end{array}$ & & & $\begin{array}{c}0.335 \\
\mathrm{p}=0.01\end{array}$ & & & & & \\
\hline Methods works & $\begin{array}{c}0.321 \\
p=0.01\end{array}$ & & & & $\begin{array}{c}0.311 \\
p=0.01\end{array}$ & & & \\
\hline $\begin{array}{c}\text { Phisical } \\
\text { conditions work }\end{array}$ & & & $\begin{array}{c}0.267 \\
p=0.05\end{array}$ & & & & & \\
\hline
\end{tabular}




\section{Conclusion}

To be able to communicate with each Terms placed diagonally, within the two Models described in this article, should be cross from one of the two adjacent Terms that acts as a 'facilitator'. In order to reach the condition of Flexible Profile or Involvement, condition of Unstable Profile or Waiver should move from being of Underused Profile or Challenge, which would mean 'get their hands dirty' through the use of low skills; otherwise the risk is to be attracted by the condition of Rigid Profile or Implementation, in a situation which could not then easily reach or even just talk to the condition of arrival Flexible Profile or Involvement.

The drive to improve and raise the level of motivation to work, does not result from the improvement of what you are able to do well, but by improving what you are not so qualified to do. In the first case, in relation to a skill already high, we will obtain that: 'a small success is a small success'. While in the second case, and compared to a low skill, in its initial phase: 'a small success is a great success'. This improvement may also contribute to build the self-esteem and self-confidence that comes from the acquisition of new skills, and, as previously reported, 'do better what you are not so qualified to do’ (Palumbo, 2006).

\section{REFERENCES}

[1] Herzberg F. (1959). The motivation to work. London: Wiley.

[2] Palumbo C. (2006). Andare oltre. Idee per lo sviluppo delle competenze trasversali (Going beyond. Ideas for the development of soft skills). Parma: Edizioni Santa Croce.

[3] Palumbo C. (2010). Andare oltre 2. Ricerche per lo sviluppo delle competenze trasversali (Going beyond 2. Research for the development of soft skills). Parma: Edizioni Santa Croce.

[4] Palumbo C. (2011). Andare oltre 3. Interpretazione del rapporto tra soggetto e mass media (Going Beyond 3. Interpretation of the relationship between the subject and the media). Parma: Edizioni Santa Croce.

[5] Palumbo C. (2013). Benessere individuale, organizzativo e sociale attraverso lo sviluppo delle competenze trasversali (Individual wellbeing, organizational and social, through the development of soft skills). il Dialogo. Agno (Svizzera): Bimestrale delle ACLI (Svizzera), 2, XXIII, 9.

[6] Quaglino G.P. (1999). Voglia di fare: motivati per crescere nell'organizzazione (Want to do more: motivated to grow in the organization). Milano: Guerini \& Associati. 